\title{
Condominium Contributions: A Matter of Priority
}

\author{
DON J. MANDERSCHEID ${ }^{\circ}$
}

The author examines the inherent problems associated with the rights of condominium corporations to collect the contributions due to them under the Condominium Property Act The Condominium Property Act allows such corporations to enforce their collection rights by an action for debt against the registered owner of the property and a legal charge against the unit title. This creates an unusual situation: the acquisition of real estate (a condo) is linked to the acquisition of personal liability for the debt of the previous titleholder. The author points out that this statutorilycreated transfer of liability conflicts with and takes away from the rights of parties dealing with a unit. The special status and priority of condominium corporations with respect to collection rights creates a reluctance on the part of prospective purchasers, mortgagees, and lien holders to acquire, finance or provide supplies or services for a condominium unit. The author, having pointed out the salient flaws in the legislation, proposes various amendments to address or ameliorate the situation and to ensure that condominium-type land ownership is able to flourish in Alberta.
L'auteur examine les problèmes inhérents aux droits des associations condominiales ou syndicats de copropriété de percevoir les contributions aux dépenses communes en vertu de la Condominium Property Act - et d'engager des actions en recouvrement contre les propriétaires inscrits et des poursuites contre les titres enregistrés, le cas échéant. Il en résulte une situation inhabituelle, puisque l'acquisition de biens réels (en copropriété) entraine l'acquisition d'une responsabilité personnelle pour la delte d'un détenteur de titre précédent. L'auteur souligne que ce transfert de responsabilite exprès est contraire aux droits des copropriétaires et les limite. Le statut particulier et la priorité des associations condominiales à cet égard a une incidence défavorable sur les acheteurs, les créanciers hypothécaires et les détenteurs de privilèges susceptibles d'acquérir, de financer une unité ou de fournir des services. Après avoir souligné les lacunes flagrantes de la législation, l'auteur propose diverses modifications visant à assurer le succès de ce régime de proprièté foncière en Alberla.

\section{TABLE OF CONTENTS}

I. INTRODUCTION . . . . . . . . . . . . . . . . 974

II. CONTRIBUTIONS AND THE POWERS OF COLLECTION $\ldots \ldots \ldots .976$

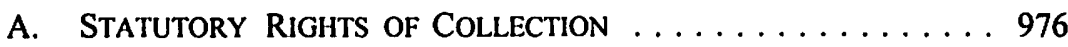

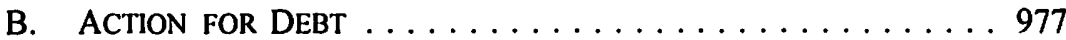

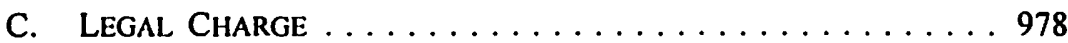

III. UNPAID CONTRIBUTIONS AND PARTIES

DEALING WITH THE UNIT . . . . . . . . . . . . 979

A. THE NEW OWNER AND SECTION 31 OF THE $A C T \ldots \ldots \ldots 979$

B. The Mortgagee $\ldots \ldots \ldots \ldots \ldots \ldots \ldots \ldots$

C. OTHER PARTIES AND, IN PARTICUlar,

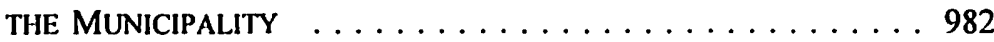

D. THE PROBLem, THE AMENDMENT

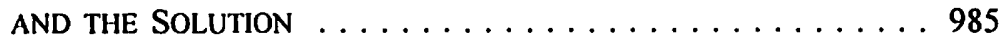

IV. ConcLusion $\ldots \ldots \ldots \ldots \ldots \ldots \ldots \ldots \ldots \ldots \ldots$

B.A., LL.B., LL.M., and legal counsel with the Law Branch, Corporate Services Department, City of Edmonton. This article reflects the views of the author only. 


\section{INTRODUCTION}

Prior to 1966, there were no condominiums in Alberta. In that year, the Alberta legislature passed the Condominium Property Act, ${ }^{1}$ and thereby ushered in a totally alien concept of land ownership. ${ }^{2}$ Notwithstanding its foreign origin, communal ownership of land by means of what is termed a "condominium" has come to form a substantial portion of today's real estate market. ${ }^{3}$

The reasons for the rapid acceptance of condominiums in Alberta are probably varied, depending upon individual needs. To a first home buyer, the drawing feature may be the purchase price. For others, especially the elderly, the attraction may be the relief provided from the tedious tasks associated with property maintenance. Whatever the reason, the condominium is now an accepted alternative to the traditional single family residential lot.

At present, the governing legislation for condominiums in Alberta is the Condominium Property Act. ${ }^{4}$ Pursuant to this legislation, a condominium is created by the registration at the Land Titles Office of a condominium plan. ${ }^{5}$ Since a condominium plan is deemed by the Act to constitute a plan of subdivision, ${ }^{6}$ registration of the plan will result in a subdivision of the land contained in the plan and the issuing of separate certificates of title for each unit described in the plan. ${ }^{7}$

In addition to effecting subdivision, registration of the condominium plan also creates a corporation. ${ }^{8}$ This corporation consists of all those persons who are owners of the units in the parcel to which the condominium plan applies or who are entitled to the parcel when the condominium arrangement is terminated. ${ }^{9}$

As a condominium corporation is an artificial person, it requires a human element to carry out its powers and duties. In fulfilling this need, the Act stipulates that a corporation shall have a board of managers, which shall be constituted as provided by

S.A. 1966, c. 19, which was entitled, "An Act to Facilitate the Division of Buildings Into Separately Owned Units."

2 The Act was modeled after the condominium legislation then in effect in New South Wales, entitled The Conveyancing (Strata Tilles Act), (N.S.W.-Aus), 1961, c. 17.

3 Statistics from the Edmonton Real Estate Board indicate that in the City of Edmonton, during the month of November, 1998, the board recorded the sale of 616 single-family dwellings as opposed to 208 condominium units. Accordingly, the sale of condominium units was roughly $1 / 3$ that of single family dwellings and therefore constituted a significant share of the residential market.

$4 \quad$ R.S.A. 1980 , c. C-22, [hereinafter $A c t$ ].

$3 \quad$ Ibid., s. 2(1).

"Ibid., s. 1.2 .

$7 \quad$ lbid., S. 3(1).

* Ibid., s. 20(1). See Royal Bank of Canada v. Beaufils (1980), 113 D.L.R. (3d) 423 at 425 (N.S. S.C T.D.) [hereinafter Beaufils], where MacIntosh J. termed this form of corporation as a "special purpose corporation," in that its sole purpose is to provide a vehicle to the unit owners through which the condominium's common property can be effectively managed.

9 Jbid., s. 20(2). 
the bylaws of the corporation. ${ }^{10}$ This board is responsible for the exercise and performance of the corporation's powers and duties. These powers and duties include the enforcement of the condominium's bylaws and the control, management and administration of the corporation's real and personal property and the common property. "I

In order for the corporation to discharge its statutory responsibilities, it must have access to a continuous supply of operating capital. In fulfilling this need, the Act provides that the corporation may establish a fund for administrative expenses. ${ }^{12}$ For the purposes of the fund and the raising of the amounts required by the corporation, the Act empowers the corporation with the ability to levy contributions on the individual unit owners in proportion to the unit factors for their respective units. ${ }^{13}$

The right to levy contributions against the unit owners would in itself be ineffectual unless, in addition, there were the means of enforcement. In an effort to provide enforcement measures, the Act permits unpaid contributions to be collected by the corporation by an action for debt ${ }^{14}$ and by the creation of a charge upon filing a caveat against the unit title. ${ }^{15}$

By virtue of the Act, a condominium unit "may devolve or be transferred, leased, mortgaged, or otherwise dealt with in the same manner as any other parcel of land held under the Land Titles Act." 16 Despite this statutory equality, due to consequences that may flow from the exercise by the corporation of its remedies as contained in the Act for collection of unpaid contributions, this may be where any similarity between the condominium unit and other forms of real property ends.

In this respect, due to the wording of the Act, should a party become the owner of a unit, the resulting transfer of ownership will effect a transfer of liability to the new owner for unpaid contributions owing with respect to the unit. ${ }^{17}$ In Adler, Furman \& Associates Ltd. v. Owners, Condominium Plan CDE 13442, ${ }^{18}$ Bowen J. aptly summated the transfer of liability as contemplated by the Act as follows:

It is to be noted particularly that the Act specifically sets out that an action in debt may be recovered by the corporation, firstly, from the owner at the time of the resolution, or secondly, from the owner at the time when the action was instituted both jointly and severally. In essence it contemplates a change in ownership and a charging of the new owner for fees owing."

Ibid., s. 23(1).

Ibid., s. 30(1).

Ibid., s. 31(1)(a).

Ibid., s. 31(1)(c).

Ibid., s. 31(2).

Ibid., s. 31(5).

R.S.A. 1980, c. L-5 [hereinafter Land Titles $A c t$ ]. See also Act, supra note 4, s. 3(3).

See Owners, Condominium Plan 8110301 v. Sohal, Sohal and Royal Bank of Canada, [1985] 2 W.W.R. 187 at 190 (Alta. Q.B.) [hereinafter Sohal]. (1984), 37 Alta. L.R. (2d) 338 (Q.B.).

Ibid. at 340 . 
Under normal circumstances, one does not associate the acquisition of real property with the acquisition of personal liability for the debt of another. Given this fact, the liability transfer as contemplated by the Act for unpaid contributions may prove problematic for prospective purchasers or parties relying upon the unit title as security for monies lent or owing. In this article, the writer proposes to discuss the collection rights of the corporation as contained within the $A c t$ and the problem created by their exercise vis-à-vis parties having an interest in, or wishing to acquire an interest in, the unit property.

\section{Contributions and the Powers of Collection}

\section{A. Statutory Rights of COLlection}

The statutory authority for the collection of contributions by the corporation is contained in $\mathrm{s} .31$ of the Act. $^{20}$ As mentioned previously, the remedies provided by $\mathrm{s}$.

Section 31 reads as follows:

31 (1)In addition to its other powers under this Act, the powers of a corporation include the following:

(a) to establish a fund for administrative expenses sufficient, in the opinion of the corporation, for the control, management and administration of the common property, for the payment of any premiums of insurance and for the discharge of any other obligation of the corporation;

(b) to determine from time to time the amounts to be raised for the purposes mentioned in clause (a);

(c) to raise amounts so determined by levying contributions on the owners in proportion to the unit factor for their respective units;

(d) to recover from an owner by an action in debt any sum of money spent by the corporation

(i) pursuant to a by-law, or

(ii) as required by a local authority or other public authority,

in respect of the unit or common property that is leased to that owner under section 41.

(2) A contribution levied as provided in subsection (1) is due and payable on the passing of a resolution to that effect and in accordance with the terms of the resolution, and may be recovered by an action for debt by the corporation

(a) from the person who was the owner at the time when the resolution was passed, and

(b) from the person who was the owner at the time when the action was instituted,

both jointly and severally.

(3) A corporation shall, on the application of an owner or a person authorized in writing by him, certify

(a) the amount of any contribution determined as the contribution of the owner,

(b) the manner in which the contribution is payable,

(c) the extent to which the contribution has been paid by the owner, and

(d) the interest owing, if any, on any unpaid balance of a contribution

and, in favour of a person dealing with that owner the certificate is conclusive proof of the matters certified in it.

(4) A corporation may file a caveat against the certificate of title to an owner's unit for the amount of a contribution levied on the owner but unpaid by him. 
31 for collection of unpaid contributions by the corporation are twofold and consist of the right to bring an action for debt and to create a legal charge against the unit title. ${ }^{21}$ There are no election provisions in the Act that require the corporation to choose one remedy over that of another. ${ }^{22}$ Consequently, the corporation does not have to exhaust its rights under one remedy prior to the exercise of the other.

\section{B. ACTION FOR DEBT}

Pursuant to s. 31(2) of the Act, unpaid contributions may be recovered by the corporation by an action for debt against the person who was the owner at the time when the resolution for the contribution was passed, and against the person who was the owner at the time when the action was instituted. This liability is joint and several. ${ }^{23}$ There is no requirement in the $A c t$ that the corporation commence its action against both particular owners or indeed as one action or as two actions. ${ }^{24}$ Further, the Act does not require that the corporation commence its action within a specific period of time. Therefore, aside from the limitation period imposed by the Limitation of Actions $A c t,{ }^{25}$ the corporation could choose to commence its action at anytime within the applicable limitation period for commencement of an action for debt. ${ }^{26}$

Given that s. 31(2) effects an imposition of personal liability on a party who may not have willingly assumed the debt, this statutory imposition constitutes an exception to the common law rule "that a person is not liable for the debt of another except by

(5) On the filing of the caveat under subsection (4) the corporation has a charge against the unit equal to the unpaid contribution.

(6) A charge under subsection (5) has the same priority from the date of filing of the caveat as a mortgage under the Land Titles Act and may be enforced in the same manner as a mortgage.

(7) The Dower Act and Part 10 of the Civil Enforcement Act do not apply to proceedings under subsection (6).

(8) If a corporation has filed a caveat under this section, the corporation on the payment to it of the amount of the charge shall withdraw the caveat. Supra notes 14 and 15.

Legislation similar to that contained in s. 31 of the $A c t$ can be found in s. 411(2)(b) of the Municipal Government Act, S.A. 1994, c. M-26.1 [hereinafter Municipal Government Act], which provides that a municipality may start an action to recover tax arrears. Alternatively, pursuant to s. 418 of the Municipal Government Act, a municipality could proceed to obtain payment of its tax arrears by sale of the property at public auction. However, this is where the similarity between these two statutes ends, given that s. 411(2)(b) of the Municipal Government Act contemplates an election of remedies to the effect that the municipality may only start an action to recover tax arrears, provided the property has not been sold at public auction, by private sale or acquired by the municipality. Section 31 of the Act does not contain a corresponding prohibition.

See Sohal, supra note 17 at 190, where Montgomery J. reiterates that the effect of s. 31(2) of the $A c t$ is to create joint and several liability on the part of the party who was the owner at the time when the resolution levying the contribution was passed, and as against the party who was the owner of the unit when the action was instituted. 490 at 499 (Sask. Q.B.).

S.A. 1996, c. L-15.1.

Ibid., s. 3(1). 
expressed agreement." 27 Despite any injustice which may result from this statutory interference with the common law, ${ }^{28}$ the language employed by the drafters of $\mathrm{s.} \mathrm{31(2)}$ leaves little doubt as to intent. ${ }^{29}$

\section{Legal Charge}

By s. $31(5)$ of the $A c t$, a caveat that has been filed by the corporation under s. 31(4) of the Act will create a charge against the unit equal to the amount of the unpaid contributions. This charge has the same priority from the date of filing as a mortgage under the Land Titles Act and may be enforced in the same manner as a mortgage. ${ }^{30}$ Upon payment of the amount of the charge, the corporation is required to discharge its caveat. $^{31}$

As is the case with the corporation's right to collect unpaid contributions through an action for debt, aside from the limitation period imposed by the Limitation of Actions $A c t,{ }^{32}$ there is no limitation period either in the $A c t$ or elsewhere that requires the corporation to file its caveat within a specific period of time. ${ }^{33}$ Accordingly, a search of the unit title which discloses the absence of a caveat by the corporation for unpaid contributions, is not indicative of the non-existence of unpaid contributions.

In the event that the corporation files a caveat under s. 31(4), the corporation could take steps by statement of claim to enforce the charge created by the filing of the caveat. Unfortunately, the Act does not specify who the party defendants shall be. Presumably, as the relief sought is in relation to the unit, the proper party defendants would be restricted to the current owner of the unit and the holders of any prior

See Canada Mortgage and Housing Corporation v. Halifax County Condominium Corporation and Crowe (1982), 52 N.S.R. (2d) 579 at 583 (N.S. S.C.T.D.), where Hallett J. held that to impose personal liability on a purchaser who has not voluntarily assumed the debt would be a departure from the common law and would require explicit language in the relevant legislation. See National Life Assurance Company of Canada v. Vidalin Construction Lid. et al. (1985), 64 B.C.L.R. 319 at 324 (S.C.), where McKenzie J. refers to this form of liability as "brutal and piratical."

See Adler, Furman \& Associates Lid. v. Owners, Condominium Plan CDE 13442 (1985), 37 Alta. L.R. (2d) 341 at 342 (C.A.), where Moir J.A., in commenting on the language of s. 31 of the Act, stated that "the liability for the condominium fees was clearly imposed on both the past and present registered owners of the condominium by s. 31(2) of the Condominium Property Act in this province."

lbid., s. 31(8).

Supra note 25, s. 3(1).

See Beaufils, supra note 8 at 426. Contra: Central Mortgage \& Housing Corp. and Winnipeg Condominium Corp. No. 1 (1975), 64 D.L.R. (3d) 186 at 189 (Man. Q.B.), where Wright J., in interpreting the effect of the words "any owner" in the Manitoba condominium legislation, held that in order for a lien for unpaid contributions to have validity and priority over subsequent owners, the lien must be registered at a time when the defaulting owner was the owner of the unit. 
registered encumbrances. ${ }^{34}$ This would appear to be consistent with the process mandated in other similar forms of legislation. ${ }^{35}$

\section{UnPaid Contributions and Parties Dealing with the Unit}

\section{A. The New OWNer and SeCtion 31 of THE $A C T$}

When land is acquired, either through contractual, judicial or statutory means, the acquiring party will usually know the extent to which the acquisition obligates them for payment of financial liabilities associated with the land. In the case of the typical land acquisition, the standard practice is to state in the agreement of purchase and sale the encumbrances that the purchaser has agreed to assume. As well, in cases involving a foreclosure by a mortgagee, the traditional order of foreclosure will provide that title to the land will issue free and clear of all encumbrances and registrations, except those which were registered prior in time. Likewise, where land is acquired through statutory proceedings, as in the case of a tax forfeiture, the enabling legislation provides that title will issue free of all encumbrances, except those specified in the statute. ${ }^{36}$

In all of the above situations, the relevant contract, judicial order or statute will dictate which registrations and accompanying financial liabilities are to be assumed by the new owner. Nevertheless, in the case of the acquisition of a condominium unit, this may not necessarily be the case.

As mentioned previously, ${ }^{37}$ should a party obtain title to a condominium unit, $\mathrm{s}$. 31(2) of the Act will cause such party to become jointly and severally liable with the party who was registered as owner of the unit at the time the resolution was passed for the unpaid contributions. This liability is strict, and ignorance as to the existence of unpaid contributions is not a recognized defense. ${ }^{38}$ The lack of judicial compassion on a party who fails to inform themselves as to the existence of unpaid contributions was strongly evident by the statement of Armstrong J. in Owners of Condominium Plan $82 R 42988$ v. Royal Bank of Canada, ${ }^{39}$ where he states:

See Athabasca (Town of) v. Shaw, [1917] 3 W.W.R. 1001 at 1002 (Alta. S.C.), where Scott J. held that where a municipality seeks an order for the sale of land to realize its lien for unpaid taxes, all persons interested in the land, and in particular, the registered owner, should be made parties to the action.

See s. 36 of the Builders' Lien Act, R.S.A. 1980, c. B-12, which specifies who the party defendants shall be.

36. See Municipal Government Act, supra note 22, s. 424.

$37 \quad$ See supra note 23.

38 See Owners of Condominium Plan $82 R 42988$ v. Royal Bank of Canada, supra note 24 at 498, where Armstrong $\mathrm{J}$. infers that the onus is on mortgagees and purchasers to inform themselves as to the status of any unpaid contributions.

Supra note 24. Contra: Wesner Drilling Co. v. Tremblay (1909), XVIII O.L.R. (D.C.) 439 at 445 , where Meredith C.J. affirmed that in cases involving a judicial salc of land, the Court "will not allow a purchaser from it to be put in an unfair position." In Wesner Drilling Co. v. Tremblay, Meredith C.J. went on to hold that, where a purchaser acquires title to land through judicial sale in the belief that title will issue free of encumbrances, the purchaser's completion of the sale in the absence of knowledge as to unpaid taxes will not disentitle the purchaser to relief by having the 
The Bank is caught as owner: It took title to a property which turns out to be worth a little less than had been anticipated - less by the amount of the unpaid assessments. It is not unlike unpaid property taxes in a sense. There can be property taxes owing without notice of such on the title to the property. A purchaser has to inquire at the offices of the taxing authority to ascertain whether taxes are paid if the purchaser wants to avoid having to pay outstanding taxes. The same is true of a purchaser of a condominium apartment. One has to inquire of the condominium corporation whether there are any outstanding assessments if one wants to be protected against their being such and having to pay them eventually. ${ }^{40}$

Given the undesired repercussions associated with the application of s. 31(2), the legal maxim of "caveat emptor" may never be more appropriate.

\section{B. THE Mortgagee}

To date, the effect of the liability transfer as contemplated by s. 31(2) has only been witnessed in cases involving mortgagees who, through foreclosure proceedings, have taken title to the unit only to find that they are now personally liable for unpaid contributions associated with the unit. A classic example of the liability problem created by s. 31(2) vis-à-vis mortgagees can be seen in the Alberta Court of Queen's Bench decision in Sohal. ${ }^{41}$

In Sohal, the individual defendants became registered owners of a condominium unit and during their time of ownership, the plaintiff condominium corporation had set monthly and special levies by passing a resolution under s. 31(1) of the Act. The individual defendants subsequently defaulted on their mortgage and the defendant bank became the registered owner of the unit through foreclosure proceedings. The plaintiff corporation then brought an action for debt pursuant to s. 3i(2) to collect the unpaid levies.

The issue to be determined by the Court was simply whether or not the bank, as the owner of the unit at the time the action was commenced, was liable to the plaintiff corporation under s. 31(2) for the unpaid contributions. In concluding that the defendant bank was liable to the corporation for the unpaid contributions, Montgomery J. had this to say:

By virtue of s. 31(2)(b) of the Condominium Property Act the plaintiff may recover by an action for debt from the owner at the time when the action was instituted the contributions levied pursuant to $s$. 31(1). In my opinion the defendant, the Royal Bank of Canada, falls into this category as it was the owner at the time this action was commenced on 8 th June 1983. Therefore, it is jointly and severally liable with the Sohals, the other defendants, who counsel agree were the owners at the time the 
resolutions were passed levying the contributions permitted by s. 31(1). By-law 52 of the plaintiff has no bearing on this decision as it is overruled by s. $31(2)(b) .^{42}$

The decision in Sohal is evidence of the literal interpretation approach that the Alberta judiciary has taken in deciphering s. 31 of the $A c t .{ }^{43}$ Although this reasoning may be correct from a strict statutory interpretation perspective, from a practical perspective it is flawed. To provide by statute that rights will be determined based upon registration of the interest at the Land Titles Office, ${ }^{44}$ and then to allow a party to usurp any priority created by registration by merely choosing to exercise one statutory remedy as opposed to another, makes little practical sense. ${ }^{45}$ This fact was recognized by Funduk M.C. in Central and Eastern Trust Company v. Borland et al., ${ }^{46}$ where he makes this comment:

If a mortgagee who obtains title to the lands by a final order of foreclosure is liable in debt for the outstanding condominium fees, there may be an absurdity in the charge the Condominium Property $A c t$ gives to secure the debt being wiped out by the order of final foreclosure. The mortgagee, as owner, is liable in debt and the charge no longer exists. However, if there is such an absurdity it is a matter for the legislators, not the court, to resolve. ${ }^{47}$

Ibid. at 190. It should be noted that in Sohal, Montgomery J. at 190, stated that Bylaw 52 of the plaintiff corporation had no bearing on the liability of the defendant bank as the contents of the bylaw were overruled by section 31(2)(b) of the Act. In this respect, the bylaw in question provided that the plaintiff corporation had a charge against the unit for all unpaid levies but that this charge was subordinate to the defendant bank's mortgage. This conclusion was reiterated by Armstrong J. in Owners of Condominium Plan $82 R 42988$ v. the Royal Bank, supra note 24 at 494. Contra: CIBC Mortgage Corp. v. Kilabuk-Bourassa (9 February 1998), N.W.T.J. No. 12, No. CV 07040 (N.W.T. S.C.), where Vertes J. concluded that a waiver in the corporation's bylaws of the priority granted under the enabling legislation, in favour of the rights of a mortgagee under a mortgage, was effective as against the corporation and its lien for unpaid contributions. However, Vertes $\mathrm{J}$. did note that, aside from his decision in regards to the waiver issue, such decision did not affect the corporation's statutory right to recover the amount owing from the owner through an action for debt.

See The Owners: Condominium Plan No. 8820814 v. Birchwood Village Greens Lid. et al. (27 May 1998), 9712-000322 (Alta. Q.B.), where Nation J., in an endeavour to limit the application of previous judicial interpretations, held that any priority arising from past cases which have judicially interpreted s. 31(2) of the Act should not be used to allow a condominium corporation to take title to the unit in a foreclosure and eliminate a prior registered mortgage, as this would be a contradiction of s. 31(6) of the Act.

Our land titles system is based upon the Torrens principle that the priority accorded a particular instrument will be determined by the time of its registration. In this respect, see s. 16 of the Land Titles Acl, supra note 16. See also The Owners: Condominium Plan No. 8820814 v. Birchwood Village Greens Lid. et al., ibid., where Nation J. makes reference to the fact that the Land Titles Act, supra note 16 , provides for priority by date of registration.

To permit a mortgagee to foreclose and obtain title to the unit only to see the corporation file another caveat for its unpaid contributions goes against s. 143 of the Land Titles Act, supra note 16, which restricts the filing of no more than one caveat for the same matter. The existence and possible conflict between s. 143 of the Land Tilles Act and s. 31 of the Act, was pointed out by the authors in F.C.R. Price \& M.J. Trussler, Mortgage Actions in Alberta (Calgary: Carswell, 1985) at 282 [hercinafter Mortgage Actions].

(1981), 14 Alta. L.R. (2d) 376 (Q.B.).

$47 \quad$ Ibid. at 379. 
Given the current state of the law relative to the position of the mortgagee in a foreclosure and the accompanying liability for unpaid condominium contributions, it is foreseeable that financial institutions may choose to institute measures intended to limit the undesired effects of this liability. ${ }^{48}$ From the perspective of the unit owner and prospective purchasers, these measures may not only be inconvenient but, more importantly, may detract from the marketability of the unit itself. This is therefore not a welcome state of affairs.

\section{Other Parties and, in Particular, the Municipality}

Mortgagees and purchasers who acquire title to the unit through foreclosure proceedings are but a few of the parties who may be adversely affected by the liability transfer as contemplated by s. 31 of the Act. What then is the fate of a bona fide purchaser under an agreement of purchase and sale, or a purchaser who acquires title to the unit through judicial sale in a builders' lien action, or that of a municipality who chooses to take title to the unit for unpaid property taxes? By virtue of s. 31, are these parties to share a common fate with mortgagees for liability for unpaid contributions associated with the unit?

To date, there is little or no judicial guidance relevant to these situations and what little exists, is usually of limited value due to the difference in the wording of the respective provincial statutes. ${ }^{49}$ Nonetheless, in view of the case law that has judicially interpreted s. 31 in fact situations involving mortgagees, there is every probability that a purchaser who acquires title to the unit through contract will share the same fate as that of a mortgagee. ${ }^{50}$ This can probably be said to apply also to parties who acquire title to the unit through judicial sale in a builders' lien action. ${ }^{51}$ However, this may not

To ensure that the contributions are paid, financial institutions may choose to require that the mortgagor post a security deposit similar to that employed by landlords in lease situations. Alternatively, financial institutions may employ the same measures as presently used in cases involving property taxes, e.g. the mortgage payment will include a tax component and the mortgagee will remit the tax payment directly or a failure to pay property taxes constitutes a breach under the mortgage etc.

See Owners of Condominium Plan $82 R 42988$ v. Royal Bank of Canada, supra note 24 at 494, where Armstrong J. concluded that "all that can be gained from looking at the relevant legislation in other provinces except Alberta is that it is different from the legislation in Saskatchewan."

See 3173763 Canada Inc. v. York Condominium Project No. 780 (1997), 10 R.P.R. (3d) 163 at 173 (Ont. C.J.), where Molloy J. implies that mortgagees and purchasers who acquire title to a unit through foreclosure proceedings will share a common fate vis-à-vis liability for unpaid contributions. See also Owners of Condominium Plan $82 R 42988$ v. the Royal Bank, supra note 24 at 498 , where Armstrong J. identifies mortgagees and purchasers as common parties who must protect themselves from personal liability for unpaid contributions.

Pursuant to ss. 39(3)(d) and 45(3) of the Builders' Lien Act, supra note 35, the Court may grant an order that the property, which is the subject of the lien, be sold. Section 45(3)(c) specifically provides that when the Court orders a sale of the property, the Court may make all necessary orders and directions for the completion of the sale and the vesting of the title to the property into the purchaser's name. Presumably, the Court would order that title issue to the purchaser free and clear of all encumbrances. The writer is unaware of any decision where the Court ordered that title vest in the purchaser free of any claim by a condominium corporation for unpaid contributions under s. 31 of the Act. However, this is not to say that the Court could not grant such an order. 
hold true for cases involving the acquisition of a unit as a result of tax forfeiture proceedings.

Pursuant to the Municipal Government Act, the municipality, as the taxing authority, has the statutory right to levy property taxes against the assessed owner of the unit. ${ }^{52}$ By virtue of this statute, property taxes due to a municipality are considered as an amount owing to the municipality and are recoverable as a debt due to the municipality. ${ }^{53}$ Further, the Municipal Government Act provides that the municipality's property taxes are to take priority over the claims of every person except the Crown and are a special lien against the taxed property. ${ }^{54}$

In the event that the property owner fails to pay his or her property taxes, the Municipal Government Act gives the municipality the right to offer the property for sale at a public auction. ${ }^{55} \mathrm{~A}$ party who purchases land at a public auction acquires it free of all encumbrances except those specifically listed in s. 423(1) of the Municipal Government $A c t .^{56}$ If the land is not sold at the public auction, the municipality may acquire title to the land. ${ }^{57} \mathrm{~A}$ municipality that becomes the owner of a parcel of land through tax recovery proceedings acquires the land free of all encumbrances except those same encumbrances as imposed on a purchaser under s. 423(1).

Currently, the issue of priority between the condominium corporation's claim for unpaid contributions and the municipality's claim for unpaid property taxes has yet to

What is the position of a claim by the Workers' Compensation Board under s. 126(1) of the Workers' Compensation Act, R.S.A. 1980, c. W-16? It is submitted that given the fact that $s$. 126(1) states "Notwithstanding anything in any other Act," a claim by the Workers' Compensation Board would have priority over a claim by a condominium corporation for unpaid contributions under s. 31 of the Act. In this respect see Alberta Treasury Branches v. Invictus Financial Corporation Lid. et al. (1986), 42 Alta. L.R. (2d) 181 at 186 (Q.B.), where Stratton J. granted priority to a claim by the Workers' Compensation Board over the claim by the municipality for business taxes, based on the exculpatory wording of s. 126(1).

Municipal Government Act, supra note 22 at s. 327, requires that a municipality prepare an annual tax role of all taxable property within the municipality. See also s. 331 of the Municipal Government Act, which states that the person liable to pay a property tax imposed is the person who, at the time the assessment was prepared or adopted, was the assessed person or who subsequently became the assessed person.

Ibid., s. 348(a)(b).

Ibid., s. 348(c)(d).

Ibid., s. 418.

Section 423(1) reads as follows:

423(l) A person who purchases a parcel of land at a public auction acquires the land free of all encumbrances, except

(a) encumbrances arising from claims of the Crown in right of Canada,

(b) irrigation or drainage debentures,

(c) registered easements and instruments registered pursuant to section 72 of

the Land Titles Act,

(d) right of entry orders as defined in the Surface Rights Act registered under the Land

Titles Act,

(e) a notice of lien filed pursuant to section 36 of the Rural Utilities Act, and

(f) a notice of lien filed pursuant to section 15 of the Rural Electrification Loan Act.

Municipal Government Act, supra note 22 at s. 424. 
be clearly decided by the Alberta courts. ${ }^{58}$ However, from a review of the relevant legislation, a final determination of this issue may favour the municipality. In this respect, pursuant to s. 65(1)(b) of the Land Titles Act, the rights of the municipality in the collection of its unpaid property taxes is recognized as an exception to the Torrens principle of indefeasibility of title. ${ }^{39}$ Further, the legislature has, by s. 348(c) of the Municipal Government Act, acknowledged that the municipality's rights in the collection of its property taxes are to have priority over competing claims. ${ }^{60}$

Given the priority status accorded a municipality's claim for unpaid property taxes by s. 65(1)(b) of the Land Titles Act and by s. 348(c) of the Municipal Government Act, it may be concluded that the municipality's rights in the collection of its property taxes and all associated actions will take priority over a claim by the corporation for unpaid contributions under s. 31 of the $A c t .{ }^{61}$ To conclude otherwise and permit a party to

See The Owners: Condominium Plan No. 76203080 v. Edmonton (City of) (3 April 1998), 960311780 (Alta. Q.B. M.C.), where Breitkreuz M.C. held that "from a commercial or business point of view," any conflict between the $A c t$ and the Municipal Government $A C t$ was to be decided in favour of the condominium corporation and its rights under the Act. The order of Breitkreuz M.C. for Summary Judgment was subsequently appealed and in The Owners: Condominium Plan No. 76203080 v. Edmonton (City of) (2I July 1998), 9603-11780 (Alta. Q.B.), Costigan J. set aside the order for Summary Judgment and held that the matter should proceed to trial. To date, counsel for the City of Edmonton has advised that this matter has yet to be dealt with by the Court. See Re Canada Mortgage \& Housing Corp. and Calgary (City of) (1987), 38 D.L.R. (4th) 475 at 480 (Alta. C.A.).

(11) Section 348 of the Municipal Government Act, supra notc 22, reads as follows:

348 Taxes due to a municipality

(a) are an amount owing to the municipality,

(b) are recoverable as a debt due to the municipality,

(c) take priority over the claims of every person except the Crown, and

(d) are a special lien

(i) on land and any improvements to the land, if the tax is a property tax, a special tax or a local improvements tax, or

(ii) on goods, if the tax is a business tax, a well drilling equipment tax or a property tax imposed in respect of a designated manufactured home in a manufactured home community. Presumably, this priority should apply not only to the municipality, should it take title to the unit under S. 425 of the Municipal Government Act, supra note 22, but, in addition, to a purchaser who acquires title to the unit either at the public auction or by private sale from the municipality. It should also be noted that given certain provisions contained in the Municipal Government Act, a municipality may not fall within the strict definition of "owner" under the $A c t$ and may therefore not, as the "owner" of the unit be liable for unpaid contributions. In this respect, under s. 1(1)(n) of the Act and s. 1(1)(u) of the Municipal Government Act, the term "owner" is defined to include the owner of the fee simple estate. Given that s. 426 of the Municipal Government Act provides that if the tax arrears for a property are paid after the municipality becomes the owner but before the municipality disposes of the property by private sale the title to the property may be revived in the name of the defaulting taxpayer, it is arguable that the municipality's ownership is to be considered as something less than a fee simple absolute estate. In this regard, certain judicial authorities have held that until such time as the period of redemption expires, the municipality or purchaser from the municipality cannot be considered as the "absolute" owner of the property. See Castor (Town of) v. Fenton (1917), 35 W.W.R. 1474 at 1485 (Alta. C.A.), where Stuart J. held that upon the expiry of the statutory redemption period, "the land is finally and irrevocably taken away from the owner." See also Excelsior Mining Co. v. Lochead (1915), 35 O.L.R. 154 at 161 (H.C.) where Boyd C., in reference to the Privy Council decision in McConnell v. Beatty, [1908] 
become the owner of the property through tax forfeiture proceedings, only to allow a competing claimant to enforce its claim by commencement of an action for debt against the new owner would render meaningless s. 65(1)(b) and s. 348(c), and any intention of the legislature to confer priority on the municipality for unpaid property taxes.

The above conclusion is supported by the Ontario Court of Appeal decision in Leavere v. Port Colborne (City of).$^{62}$ In that case, the Court of Appeal reasoned that to grant the municipality the statutory power to levy distress for unpaid business taxes upon chattels that are encumbered by security agreements, only to permit the holders of the security agreements to have priority over the municipality in the collection of its business taxes, is absurd. ${ }^{63}$ In this respect, Galligan J.A., speaking for the Court of Appeal, had this to say:

It would, in my view, amount to an absurdity if the statute authorized distress upon chattels covered by security agreements, but did not intend as well that the lien created by the exercise of the right of distress was to have priority over the security agreement. The power to distrain upon chattels subject to security agreements would be rendered nugatory if the security agreements were not required to rank behind the liens, which had arisen, by rule of law. The Legislature cannot have intended that the statutory right, which it granted, to distrain on such chattels was to be without effect. ${ }^{\text {(t) }}$

It is submitted that an analogy may be made between a fact situation such as existed in Leavere v. Port Colborne (City of), ${ }^{65}$ where the municipality's right to distrain for business taxes was held to have priority over the holders of security agreements, and a situation involving the competing claims of the municipality, for unpaid property taxes under the Municipal Government Act, and a condominium corporation, for unpaid contributions under s. 31 of the Act. Based on this analogy, the municipality's claim for unpaid property taxes should have priority over that of the condominium corporation for unpaid contributions. Although this reasoning may be sound, it is only speculation, and, until the Alberta judiciary conclusively rules on this matter, we can only predict as to the outcome.

\section{The Problem, the Amendment and the Solution}

From the previous discussion, it is clear that the transfer of liability for unpaid contributions as contemplated by s. 31 of the $A c t$, has created a problem for parties

A.C. 82 at 88 (P.C.), affirmed that the point in time when the purchaser becomes the effective owner of the property is when there has been a failure to redeem within the statutory period and a certificate of sale has issued to the purchaser. See also Graham v. The Trustees of Broadview School District (1893), 3 T.L.R. 200 at 204 (Terr. S.C.), where Wetmore J. held that until such time as the statutory redemption period expires, a purchaser from the taxing authority was not to be considered as the "absolute" owner because such party could not exercise all of the acts of an absolute owner. (1995), 25 M.P.L.R. (2d) 122 (Ont. C.A.) [hereinafter Leavere]. See also 1064521 Ontario Lid., $\operatorname{Re}$ (1998), 18 R.P.R. (3d) 81 at 91 (Ont. C.J.).

6.) Leavere, ibid. at 131. See also 1064521 Ontario Lid., Re (1998), ibid.

(4) Leavere, ibid.

is Supra note 62. 
dealing with the unit. The blame for this problem must rest with the legislative draftsmen who, through the $A c t$, have given the condominium corporation special status in the collection of its contributions. Why the interests of the corporation in unpaid contributions are treated differently from the interests of other security holders such as mortgagees is not answered by the Act.$^{66}$ Nonetheless, it is clear that this special status may be at the expense of purchasers, mortgage lenders and lien holders who, in order to protect themselves from liability under s. 31, may be leery to acquire, finance or perform work or provide materials in cases involving a condominium unit.

The problem created by s. 31 of the Act can only be remedied by a change in the legislation. To echo the words of Funduk M.C. in Central and Eastern Trust Company v. Borland et al. ${ }^{67}$ resolution of the problem must come from the legislature and not the courts. ${ }^{68}$ In an effort to provide parity between the unit owner and parties dealing with the unit and for purposes of clarifying the intent of s. 31, the Alberta legislature has recently proposed three significant amendments to s. $31 .{ }^{69}$

The first of these amendments provides that the owner, purchasers and mortgagees or their respective solicitors, or a person authorized in writing by any of those persons, shall be entitled to obtain a certificate under s. 31(3) of the Act. $^{70}$ At present, s. 31(3) requires that, upon receipt of a written request from the owner or any person authorized in writing by the owner, the corporation shall certify the amount, manner of payment, the extent of payment and the interest owing with respect to the contribution of the owner. Further, s. 31(3) specifically states that "the certificate is conclusive proof of the matters certified in it." In the conveyance of condominium units, it is a strict requirement to obtain an estoppel certificate from the corporation as to outstanding contributions associated with the unit. This amendment will have the effect of enabling these additional parties to obtain the same security, which is presently reserved to the unit owner, by providing direct access to the corporation for an estoppel certificate. This is therefore a welcome amendment.

Why are condominium corporations given the right to hold a party personally liable for unpaid contributions when parties such as mortgagees are presently prohibited from suing on the personal covenant? In this respect, see s. 41 (1) of the Law of Property Act, R.S.A. 1980, c. L-8, which restricts the rights of the mortgagee or unpaid vendor to the land which is the subject of the mortgage or agreement for sale and further prohibits such parties to commence an action against the mortgagor or purchaser on a covenant for payment contained in the mortgage or agreement for sale. Supra note 46.

c* Jbid. at 379. For a concise overview of s. 31 of the $\mathrm{Act}$ and its adverse effect on mortgagees, please see Mortgage Actions, supra note 45 at 278-83, where at 280, the learned authors discuss the "absurdity" of the legislation as referred to by Funduk M.C. in Central \& Eastern Trust Co. v. Borland et al., supra note 46. Section 32 of the Condominium Property Amendment Act, S.A. 1996, [unproc] c. 12. Ibid., s. 32(c). Please note that a similar provision presently exists in s. 36 of the Act. It is interesting to note that the list of parties in s. 36 who may obtain the information does not extend to persons authorized by such parties. Furthermore, the Condominium Property Amendment Act, ibid., does not contain an amendment to s. 36 similar to that proposed for s. 31(3). 
The second proposed amendment enables a mortgagee to pay unpaid contributions that are owing with respect to the unit that is the subject of the mortgage security and to add the amount paid to the amount owing under the mortgage. ${ }^{71}$ While it may be argued that a mortgagee could easily provide for a right of payment and recovery of unpaid contributions in the mortgage document itself, the fact that this right is now authorized by statute removes all doubt as to enforceability. As business is dependent upon the security of one's investment, this amendment is therefore not only welcome but also essential. The third of these amendments deals with the status of a corporation's caveat for unpaid contributions in cases where title transfers as a result of a foreclosure action, an action for specific performance or by virtue of a public auction held pursuant to tax recovery proceedings. This amendment contemplates the addition of a new subsection (9) to s. 31 of the $A c t .{ }^{72}$ Essentially, this new subsection provides that notwithstanding s. 31(6) of the $A c t$ and any priority in registration that a party's interest may have, the corporation's rights of collection for unpaid contributions, as protected by a caveat filed under s. 31(4) of the $A c t$, are to take priority over the rights of a party who acquires title to the unit through foreclosure, specific performance proceedings or by acquisition at a tax recovery public auction. If this is the intention of the proposed new s. 31(9), then this amendment has the effect of not only rendering redundant any rules of priority provided by the $A c t^{73}$ and the Municipal Government $A c t^{74}$ but in addition, those provided by registration under the present land titles system. ${ }^{75}$

Ibid., s. 32(b).

This amendment reads as follows:

(d) by adding the following after subsection (8):

(9) Notwithstanding subsection (6), if

(a) a corporation has filed a caveat under this section,

(b) subsequent to the caveat's being filed another person gains title to the unit pursuant to

(i) a foreclosure action,

(ii) an action for specific performance, or

(iii) a public auction conducted under Part 10, Division 8 of the Municipal Government Act,

and

(c) an amount remains owing to the corporation with respect to the contribution for which the caveat was filed,

that caveat shall remain registered against the certificate of title of the unit until the amount owing is paid to the corporation.

n. See supra note 30.

14 See supra note 60 . In addition, by requiring that a purchaser at a tax recovery public auction take title to the unit subject to a corporation's caveat for unpaid contributions, the proposed new $s$. 31 (9)(b)(iii) conflicts with s. 423(1) of the Municipal Government Act, supra note 22 and the purchaser's right at a tax recovery public auction to acquire title to the unit frec of all encumbrances except those specifically listed under s. 423(1), supra note 56. If it is the intention of the legislature to add to the list of permitted encumbrances as stated in s. 423(1), then simply why not do so? of Property Act, supra note 66, which provides that the effect of an order of foreclosure of a mortgage or encumbrance is to vest the title to the land "free from all right and equity of redemption on the part of the owner, mortgagor or encumbrancer or any person claiming through or under him subsequently to the mortgage or encumbrance"? See also Central \& Eastern Trust Co. v. Borland et al., supra note 46 at 378, where Funduk M.C. discussed the effect of s. 44(1) of the Law of Property Act, (then s. 109(1) of the Land Tilles Act, R.S.A. 1970, c. 198), in the 
Although this amendment will have an effect on the manner in which a unit is sold under foreclosure or specific performance proceedings, the party most adversely affected by the amendment is the municipality. The reason for this discrepancy lies in the fact that a purchaser at a tax recovery public auction does not qualify as one of the privileged few who, under ss. $31(3)$ and 36 of the $A c t$, may obtain information as to the amount of any outstanding contributions owing relative to the unit. ${ }^{76}$ Accordingly, such a purchaser is placed in the precarious position of having to decide whether or not to submit a bid to acquire the unit, without first having ascertained the amount of any unpaid contributions. In the absence of this knowledge, it is reasonable to conclude that few, if any, persons would be willing to acquire the unit. Consequently, the municipality may now find itself unable to recover its unpaid property taxes by sale of the unit at public auction.

From the previous discussion, it is clear that, although certain of the proposed amendments to s. 31 are definitely an improvement, they do not remedy the problem created by s. 31 of the Act and, in certain cases, create more problems. As an alternative, it is suggested that the curative amendment should be in the form of requiring that the corporation elect its remedy between the commencement of an action for debt or the enforcement of its legal charge. Furthermore, the corporation should be required to make its election within a specific period of time. Parties dealing with the unit must, prior to commitment, know the extent of their exposure to liability for the unpaid contributions. It is submitted that the above-suggested amendments may accomplish this goal.

\section{CONClusion}

When, in 1966, the Alberta legislature passed the Act, little thought was probably given to the possibility that condominium units may, as a result of unpaid contributions, become a liability rather than an asset. ${ }^{77}$ Aside from what might be termed a legislative over-sight, where over a prolonged period of time contributions are permitted

context of a foreclosure and the priorities between a prior registered mortgage and a corporation's caveat for unpaid contributions. Contra: Owners Condominium Plan No. 772, 1595 v. Greenacre Homes Lid., Alta. Q.B., Edmonton No. 8203-22545 (unreported) and Adler, Furman \& Associates Ltd. v. Owners, Condominium Plan CDE 13442, supra note 18 at 340 . See also Mortgage Actions, supra note 45 at 281 , where the learned authors point out that to permit the corporation's caveat for unpaid contributions to survive a foreclosure will render meaningless s. 31(6) of the Act.

As stated previously, this right, even with the proposed amendment to s. $31(3)$ of the $A c t$, is restricted to the owner, purchasers and mortgagees or their respective solicitors, or a person authorized in writing by any of those persons. As a potential purchaser at a tax recovery public auction cannot be considered as a "purchaser" of the unit until their bid is accepted by the municipality, such party, in the absence of authorization by one of the listed parties, would not have the right to request a statement disclosing the amount of the outstanding contributions relative to the unit. As well, the writer is unaware of any statutory provision that would enable the municipality to obtain this information. Given that an owner, purchaser or mortgagee would gain little by having the unit sold at the public auction, it is conceivable that such parties may be reluctant to provide the required authorization to such a potential purchaser or the municipality. See Canada Mortgage and Housing Corporation v. Halifax County Condominium Corporation and Crowe, supra note 27 at 583. 
to accumulate, it is conceivable that the owner's equity in the unit may be foreclosed by the amount of the outstanding contributions and accrued interest. ${ }^{78}$ When this occurs, the possibility of attracting liability under s. 31 of the Act may outweigh any benefit derived by the acquisition of title to the unit.

Understandably, where outstanding contributions and accrued interest have foreclosed the unit owner's equity in the unit, the liability exposure created by s. 31 may deter prospective purchasers. Furthermore, this liability exposure may prompt parties such as mortgagees and municipalities to forego their right to acquire title to the unit in favour of less risky alternative measures. ${ }^{79}$ In these situations, in order to protect the interests of the remaining unit owners and to preserve the integrity and viability of the condominium scheme, the condominium corporation may be required to take steps to acquire title to the unit. ${ }^{80}$

At such time as the corporation shall have concluded its legal proceedings and obtained title to the unit, it is reasonable to expect that the corporation would want to recover outstanding maintenance costs and condominium contributions associated with the unit, through sale of the unit. ${ }^{81}$ Regrettably, the fate of previous holders of security in the unit may taint the unit's marketability and may cause financial institutions to be reluctant to finance an acquisition of the unit by a prospective purchaser. Although

See The Owners: Condominium Plan No. 8820814 v. Birchwood Village Greens Lid. et al., supra note 43, where Nation J. dealt with an application by a condominium corporation to foreclose on the unit as there was no equity in the unit above the interest of the condominium corporation for unpaid condominium costs.

Situations similar to those where outstanding contributions and accrued interest have foreclosed the unit owner's equity in the unit may be seen in cases involving property which is environmentally contaminated, and the costs of remediation outweigh the market value of the property. In cases involving contaminated property, it has been the writer's experience that, in order to shield oneself from liability associated with the contaminated property under the Environmental Protection and Enhancement Act, S.A. 1992, c. E-13.3, neither the owner, the mortgagee or municipality usually wish to acquire title to the property. In these cases, owners have been known to abandon the property and mortgagees to cut their losses and not to proceed with foreclosure proceedings. In the case of municipalities, the writer has witnessed that municipalities are somewhat leery to take possession or title to the property and will, if possible, endeavour to collect their unpaid taxes by the alternate method of an action under s. 411(2) of the Municipal Government Act, supra note 22.

Maintenance of the unit is but one factor that may give rise to action by the corporation. In cases where a unit owner fails to pay their proportionate share of the common expenses, this share will have to be paid for by the remaining solvent unit owners. In these cases, it is only a matter of time before the remaining solvent unit owners may require that the corporation take steps to collect the unpaid contributions. See Canada Mortgage and Housing Corporation v. Halifax County Condominium Corporation and Crowe, supra note 27 at 583, where Hallett J. although sympathizing with these unit owners, pointed out that this "is a result of having entered into a form of home ownership involving joint sharing of expenses with others who, due to financial conditions, are unable to carry their share of the common expenses."

" Conceivably, the corporation could choose merely to lease the unit as opposed to selling it. However, because the corporation would now, as the owner of the unit, be responsible for the property taxes, contributions and maintenance costs associated with the unit, together with carrying the previously outstanding contributions on its books, the better course may be to sell the unit. 
initially intended as a benefit in the operation of the condominium, s. 31 may, under the present circumstances, ultimately prove to be a detriment.

If the condominium concept of land ownership is to continue to flourish in this province, the respective rights of the condominium corporation and parties having an interest in the unit must be protected by the Act. Section 31(6) of the Act contemplates this mutual recognition by dictating the manner of priority of the interests of the respective parties. However, the right to bring an action for debt under s. 31(2) of the $A c t$, and certain of the recently proposed amendments to s. 31 complicates what may otherwise be a workable arrangement.

Resolution to the problem created by $\mathrm{s} .31$ can only come from the legislature through amendment of the $A c t .^{82}$ If not forthcoming, condominium corporations may find themselves responsible for the costly maintenance and upkeep of unwanted units, which have little or no marketability and which are considered a liability rather than an asset. Perhaps in considering the required amendment, the foregoing discussion and suggestions may be of assistance. 